\title{
Polyol mixture supplementation in the diet of breeding sows and piglets
}

\author{
Matti Näsi ${ }^{1}$ ) and Timo Alaviuhkola ${ }^{2}$ )
}

1) Department of Animal Husbandry, University of Helsinki, $00710 \mathrm{Helsinki} 71$

2) Swine Research Station, 05840 Hyvinkää 4

\begin{abstract}
In a factorial $2 \times 2$ experiment the use of a polyol mixture (sugar alcohols) in the diet of sows and piglets was investigated. The trial was performed with 26 sows divided into two groups. The polyol sows were fed $180 \mathrm{~g}$ polyol mixture daily, and for polyol group piglets the polyol supplementation in creep feed was $5 \%$.

The average number of piglets per litter in the control group was 10.3 and in the polyol group 9.2. The addition of polyols to the diet of sows had only a small effect on the performance of piglets. The piglets receiving polyols in creep feed gained during 1-21 days post partum $21.1 \%$ more than controls and during the rest of the lactation period $7 \%$ more $(\mathrm{P}>0.05)$. The incidence of diarrhoea in piglets of polyol groups was slightly higher compared with controls. The consumption of creep feed supplemented with polyols tended to be higher than consumption of control feed.

Colostrum and milk samples were taken for analysis within $12 \mathrm{~h}$ after feeding and 7 and 21 days thereafter. The protein and lactose contents of colostrum and milk were slightly higher and the fat content lower from sows receiving polyols, but the differences were not significant. The mineral and amino acid composition was also analysed.
\end{abstract}

\section{Introduction}

The mixture of polyols or sugar alcohols, is a by-product of xylitol production from birch tree hydrolysate. Recent reviews by Touster (1974) and Tuorl and Poutiainen (1977) have dealt with various aspects of the metabolism of polyols.

Polyols apparently have important antimicrobial effects. Xylitol exercises an inhibitory effect on dental caries by decreasing the bacterial growth on teeth (Schein and MÄKINEN 1975). The fermentation of polyols by rumen microbes is slow compared with monosaccharides (Poutiainen et al. 1976). The findings of Korhonen et al. (1977) and MäKInEN et al. (1979 a) indicate an increase in lactoperoxidase activity in milk and saliva of cows on polyol feeding. Lactoperoxidase enzyme is antimicrobial against intestinal infections in the newborn (REITER 1978). Difficulties in piglets during the suckling period and after weaning are most frequently associated with gastrointestinal 
disorders due to bacterial overgrowth, usually of Escherichia coli. Recent findings on antimicrobial effects of polyols and lactoperoxidase enzyme were thus a motivation toward the present study.

The satisfactory growth of piglets in the period before and after weaning depends on a high voluntary intake of creep feed. The palatability of the feed is of great importance, and feed consumption increases when sweetening in gredients, e.g. sugar, are added. Study of the possible use of polyol mixture as a sweetener was the other purpose of this work.

The study is part of a research project directed at the utilisation of sugar alcohols in the nutrition of domestic animals. The effect of polyol supplementation on piglet performance and composition of the colostrum and milk of sows was investigated. The enzyme activity of sow milk during polyol feeding has been reported by MäKINEN et al. (1979 b).

\section{Materials and methods}

The experiment was carried out with 26 Landrace sows of the Swine Research Station. All sows were fourth or more parity animals at the beginning of the experiment. Three weeks before farrowing the sows were allocated at random to the control or polyol group. The sows received before farrowing $3.2 \mathrm{~kg}$ gestation ration daily, plus $180 \mathrm{~g}$ of polyol mixture in the polyol group and $100 \mathrm{~g}$ of barley in the control group daily. During the lactation period the sows were fed a lactation ration in proportion to the number of piglets $(2.8$ $\mathrm{kg}+0.3 \mathrm{~kg} /$ piglet feed daily). The sows in the polyol group continued to receive $180 \mathrm{~g}$ of polyol mixture and the control sows $100 \mathrm{~g}$ barley during the lactation period.

After farrowing, the control and polyol groups were divided into two subgroups with respect to the creep feed for piglets. The four groups were as follows:

Group 1 Control sows, control piglets, 5 litters

Group 2 Control sows, polyol piglets, 5 litters

Group 3 Polyol sows, control piglets, 5 litters

Group 4 Polyol sows, polyol piglets, 5 litters

The creep feed for piglets was supplemented with either $5 \%$ of polyol mixture or $2.5 \%$ of a mixture of glucose and tructose. The creep feed was offered to piglets after one week of age and the feed consumption was measured beginning at three weeks of age. The piglets were weighed at birth and weekly thereafter. A check for diarrhoea was made daily. Weaning took place at $\mathbf{5}$ weeks.

Feed analyses were made by standard methods (PALOHEImo 1969) and sugar alcohol composition of the polyol mixture was analysed with a gas chromatograph (Carlo Erba 180).

Milk samples from 26 sows, 13 of the control group and 13 of the polyol group, were obtained for chemical analysis by intramuscular injection of 10 IU of oxytocin, followed by manual expression of milk from several teats. 
The samples were collected at $12-16$ hours, 7 days and 21 days after farrowing and strored at $-20^{\circ} \mathrm{C}$ until analysed. After thawing the milk samples were analysed for total solids, ash, fat by the Gerber method, nitrogen by the Kjeldahl method, protein by multiplying the value of nitrogen by 6.38 , and lactose by the chloramine-T method. The amino acid composition was analysed with a gas chromatograph (Hewlett Packard $5710 \mathrm{~A}$ ), the mineral content with an atomic absorption spectrophotometer (Varian Techtron AA 1000), and phosphorus by the method of TAUSSKY and SHORR (1953).

The average weight gain of piglets for each group was tested by two-way variance analysis. The data of milk composition was tested by one-way variance analysis. The differences between treatment means were tested by the Tukey-test (STEEL and Torrie 1960).

\section{Results and discussion}

The composition of the diets is presented in Table 1. The ash content of creep feed in the control ration was 4 percentage points higher than in the polyol ration and also the DCP percentage and FU-value were lower in the control diet. This difference is probably due to a mistake in the preparation of the creep feed mixture. The average dry matter percentage of the polyol mixture was 56.8 and the sows were fed $102 \mathrm{~g}$ DM of polyol mixture daily, corresponding approximately to $0.5 \mathrm{~g}$ polyols per $\mathrm{kg}$ live weight. In creep feed the percentage of polyol supplementation was 5.0 or $28 \mathrm{~g}$ polyol DM/kg feed. The polyol mixture used in this study had the following composition, \% in dry matter: arabinitol 24.2, mannitol 19.5, sorbitol 16.2, xylitol 20.8, galactitol 5.8, rhamnitol 11.6 and other sugar alcohols and reducing sugars 1.9.

The mean values of sow and litter performance are given in Table 2 and Figure 1. The litter size differed in the two groups: the average number of piglets per litter in the control group was 10.3 and in the polyol group 9.2 .

The percentage of stillborn piglets in the control group was 6.8 and in the polyol group 10.2. In one litter in group 4 the number of stillborn was six of fourteen born. If this litter is excluded the correspoinding percentage is 6.5. Litter mortality from birth to 21 days was one piglet in group 1 and one in group 2; afterwards no death of piglets occurred.

The different size of litters caused some anomalies in the results. The treatments had no statistically significant effect on growth of the piglets when the number of piglets per litter was treated as an independent variable. The supplementation of polyol mixture in the diet of sows had only a small effect on the performance of piglets. The growth rate of the litters of sows receiving polyol supplement was in the period $1-21$ days post partum 6.6 percent better, but the number of piglets should be take into account, which was on average 1.1 piglets less. During the whole lactation period the difference was quite small. The piglets receiving polyol mixture in the creep feed gained during 1-21 days post partum 21.1 per cent more than piglets in the control group and during the rest of the lactation period $7-8 \%$ more. In the whole experimental period the response of growth rate to polyol supplementation amounted to an average $10.1 \%$ increase. Reduction in the number 
Table 1. Composition of the diets.

\begin{tabular}{|c|c|c|c|c|}
\hline \multirow{2}{*}{ Ingredients, $\%$} & \multirow{2}{*}{ Gestation } & \multirow{2}{*}{ Lactation } & \multicolumn{2}{|c|}{ Creep feed } \\
\hline & & & Control & Polyol \\
\hline 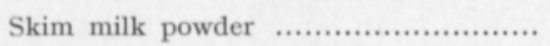 & - & 3.0 & 25.0 & 25.0 \\
\hline 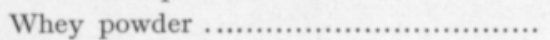 & - & - & 10.0 & 10.0 \\
\hline Soybean meal ................................ & 5.0 & 5.0 & 7.0 & 7.0 \\
\hline 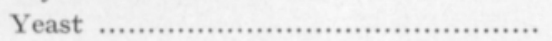 & - & - & 1.5 & 1.5 \\
\hline Fish meal .................................... & 5.0 & 5.0 & - & - \\
\hline 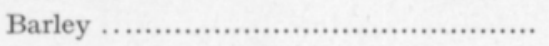 & 43.0 & 42.0 & - & - \\
\hline 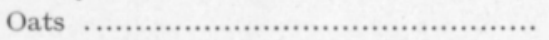 & 43.3 & 41.2 & - & - \\
\hline Oatmeal ........................................... & - & - & 50.7 & 48.2 \\
\hline Sugar alcohols ............................... & - & - & - & 5.0 \\
\hline Fructose + glucose $\ldots \ldots \ldots \ldots \ldots \ldots \ldots \ldots \ldots \ldots \ldots \ldots \ldots \ldots \ldots$ & - & - & 2.5 & - \\
\hline Mineral and vitamin supplements ........ & 3.7 & 3.8 & 3.3 & 3.3 \\
\hline \multicolumn{5}{|l|}{ Chemical composition, $\%$ in DM } \\
\hline 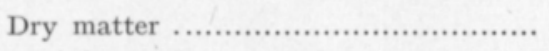 & 88.3 & 88.4 & 88.7 & 88.3 \\
\hline 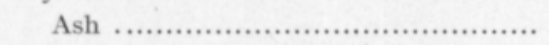 & 6.3 & 6.5 & 11.8 & 7.8 \\
\hline 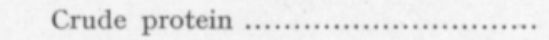 & 17.6 & 18.2 & 21.2 & 22.5 \\
\hline Ether extract ............................... & 3.9 & 3.6 & 3.3 & 3.8 \\
\hline 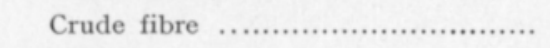 & 7.0 & 7.0 & 3.2 & 2.6 \\
\hline 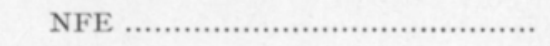 & 65.2 & 64.7 & 60.5 & 63.3 \\
\hline \multicolumn{5}{|l|}{ Feed values } \\
\hline 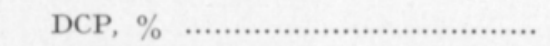 & 13.0 & 13.5 & 16.6 & 17.5 \\
\hline 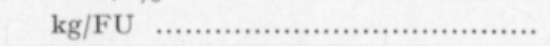 & 1.09 & 1.10 & 0.99 & 0.95 \\
\hline
\end{tabular}

$1 \mathrm{FU}=0.7 \mathrm{~kg}$ starch.

Fig. 1. Live-weight gain of the piglets in different groups.

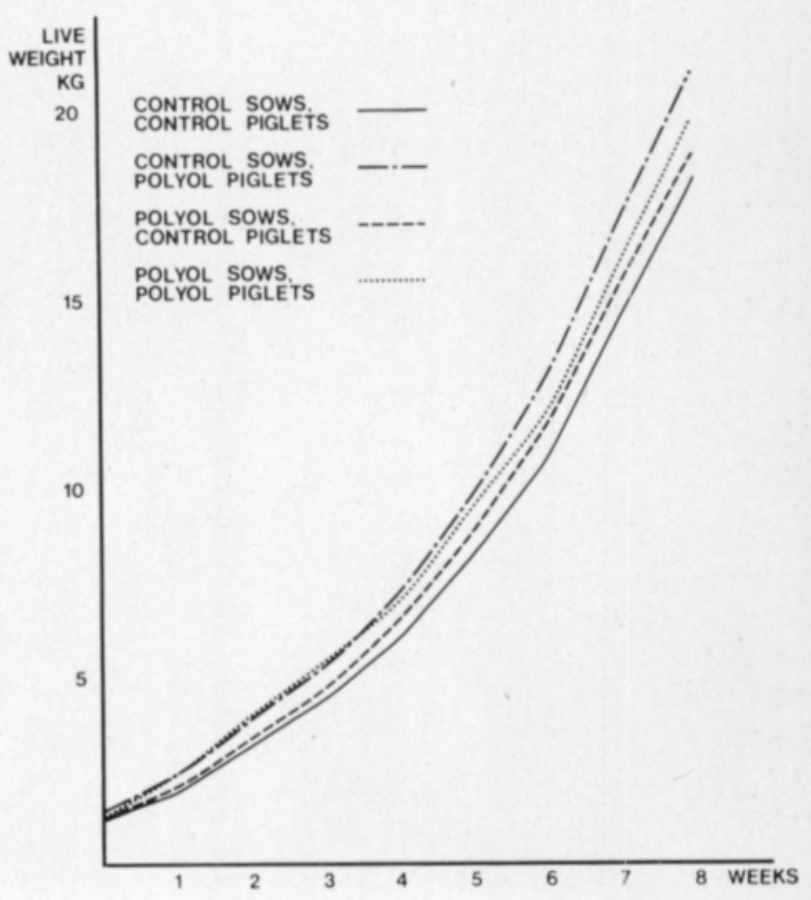


Table 2. Average daily gain, feed intake and feed efficiency of piglets.

\begin{tabular}{|c|c|c|c|c|c|c|c|c|}
\hline \multirow[t]{2}{*}{ Group } & \multirow{2}{*}{$\begin{array}{c}1 \\
\text { Control } \\
\text { Control } \\
\mathbf{x}\end{array}$} & $\begin{array}{l}\text { sows } \\
\text { piglets }\end{array}$ & \multicolumn{2}{|c|}{$\begin{array}{c}2 \\
\text { Control sows } \\
\text { Polyol piglets }\end{array}$} & \multicolumn{2}{|c|}{$\begin{array}{c}3 \\
\text { Polyol sows } \\
\text { Control piglets }\end{array}$} & \multirow{2}{*}{$\begin{array}{c}{ }^{4} \\
\text { Polyol } \\
\text { Polyol } \\
\mathbf{x}\end{array}$} & \multirow{2}{*}{$\begin{array}{l}\text { sows } \\
\text { piglet: } \\
\text { s.d. }\end{array}$} \\
\hline & & s.d. & $\mathrm{x}$ & s.d & $\mathbf{x}$ & s.d. & & \\
\hline No of litter .............. & 5 & & 5 & & 5 & & 5 & \\
\hline Total piglets .............. & 57 & & 46 & & 50 & & 42 & \\
\hline Piglets/litter ............... & 11.4 & & 9.2 & & 10.0 & & 8.4 & \\
\hline \multicolumn{9}{|l|}{ Daily gain, g/d } \\
\hline $0-21 \mathrm{~d} \ldots \ldots \ldots \ldots .$. & $151^{\mathrm{a}}$ & 31 & $183^{\mathrm{a}}$ & 53 & $160^{\mathrm{a}}$ & 37 & $195^{\mathrm{a}}$ & 52 \\
\hline $22-35 \mathrm{~d} \ldots \ldots \ldots \ldots .$. & $272^{\mathrm{a}}$ & 59 & $311^{\mathrm{a}}$ & 74 & $292^{\mathrm{a}}$ & 71 & $293^{a}$ & 62 \\
\hline $36-56 \mathrm{~d} \ldots \ldots \ldots \ldots .$. & $477^{a}$ & 71 & $534^{\mathrm{a}}$ & 85 & $476^{\mathrm{a}}$ & 78 & $490^{\mathrm{a}}$ & 85 \\
\hline $0-56 \mathrm{~d} \ldots \ldots \ldots \ldots . .$. & $303^{a}$ & 45 & $347^{a}$ & 62 & $312^{\mathrm{a}}$ & 52 & $330^{\mathrm{a}}$ & 53 \\
\hline \multicolumn{9}{|l|}{ Feed intake $\mathrm{kg} /$ piglet } \\
\hline $22-35 \mathrm{~d} \ldots \ldots \ldots \ldots . .$. & 1.5 & & 1.5 & & 1.7 & & 1.1 & \\
\hline $36-49 \mathrm{~d} \ldots \ldots \ldots \ldots . .$. & 10.3 & & 11.1 & & 10.9 & & 10.9 & \\
\hline $50-56 \mathrm{~d} \ldots \ldots \ldots \ldots$ & 7.5 & & 8.6 & & 7.8 & & 8.3 & \\
\hline $22-56 \mathrm{~d} \ldots \ldots \ldots \ldots$ & 19.2 & & 21.2 & & 20.3 & & 20.3 & \\
\hline \multicolumn{9}{|l|}{$\begin{array}{l}\text { Feed efficiency } \\
\text { kg creep feed/kg gain }\end{array}$} \\
\hline $22-35 \mathrm{~d} \ldots \ldots \ldots \ldots$ & 0.39 & & 0.35 & & 0.40 & & 0.28 & \\
\hline $36-49 \mathrm{~d} \ldots \ldots \ldots \ldots$ & 1.65 & & 1.50 & & 1.64 & & 1.71 & \\
\hline $50-56 \mathrm{~d} \ldots \ldots \ldots \ldots$ & 1.98 & & 2.20 & & 2.32 & & 2.12 & \\
\hline
\end{tabular}

Means with different letters were significantly different $(\mathrm{a}, \mathrm{b} \mathrm{P}<0.05)$.

of piglets per litter should be taken account when evaluating the results. The health of sows and piglets was normal during the experiment. The incidence of diarrhoea was 7, 6, 8, and 11 in 5 litters in groups 1, 2, 3 and 4, respectively during the rearing period. Piglets in two litters of the polyol group had to be treated clinically. Other cases of diarrhoea were quite slight. The polyol feeding did not raise the lactoperoxidase content of sow milk (MÄKINEN et al. 1979 b).

Table 3. Contents of milk constituents at different sampling times.

\begin{tabular}{|c|c|c|c|c|c|c|c|c|c|c|c|c|}
\hline \multirow{3}{*}{$\begin{array}{l}\text { Time after } \\
\text { farrowing }\end{array}$} & \multicolumn{6}{|c|}{ Control diet } & \multicolumn{6}{|c|}{ Polyol diet } \\
\hline & \multicolumn{2}{|c|}{$12 \mathrm{~h}$} & \multicolumn{2}{|c|}{$7 \mathrm{~d}$} & \multicolumn{2}{|c|}{$21 \mathrm{~d}$} & \multicolumn{2}{|c|}{$12 \mathrm{~h}$} & \multicolumn{2}{|c|}{$7 \mathrm{~d}$} & \multicolumn{2}{|c|}{$21 \mathrm{~d}$} \\
\hline & $\overline{\mathbf{x}}$ & s.d. & $\bar{x}$ & s.d. & $\overline{\mathbf{x}}$ & s.d. & $\overline{\mathbf{x}}$ & s.d. & $\bar{x}$ & s.d. & $\bar{x}$ & s.d. \\
\hline $\mathrm{n}$ & \multicolumn{2}{|c|}{13} & \multicolumn{2}{|c|}{13} & \multicolumn{2}{|c|}{13} & \multicolumn{2}{|c|}{13} & \multicolumn{2}{|c|}{13} & \multicolumn{2}{|c|}{13} \\
\hline Total solids, \% & $18.15^{\mathrm{a}}$ & 1.82 & $18.40^{\mathrm{a}}$ & 1.19 & $17.56^{\mathrm{a}}$ & 1.26 & $18.71^{\mathrm{a}}$ & 2.18 & $18.24^{\mathrm{a}}$ & 0.97 & $17.67 \mathrm{a}$ & 0.57 \\
\hline Ash, $\%$ & $0.65^{a}$ & 0.06 & $0.76^{\mathrm{a}}$ & 0.09 & $0.71 \mathrm{a}$ & 0.06 & $0.70^{\mathrm{a}}$ & 0.08 & $0.68^{\mathrm{b}}$ & 0.05 & $0.72^{\mathrm{a}}$ & 0.09 \\
\hline Fat, \% & $5.46^{\mathrm{a}}$ & 1.74 & $7.32^{\mathrm{a}}$ & 1.11 & $6.09^{\mathrm{a}}$ & 0.93 & $5.36^{\mathrm{a}}$ & 1.69 & $7.16^{\mathrm{a}}$ & 0.97 & $5.98^{a}$ & 0.65 \\
\hline Protein, \% & $7.97^{a}$ & 1.94 & $5.02^{\mathrm{a}}$ & 0.33 & $4.81^{\mathrm{a}}$ & 0.30 & $8.50^{\mathrm{a}}$ & 2.25 & $5.19^{\mathrm{a}}$ & 0.54 & $4.98^{\mathrm{a}}$ & 0.35 \\
\hline $\begin{array}{l}\text { Protein in dry } \\
\text { matter, } \%\end{array}$ & $43.8^{\mathrm{a}}$ & 8.7 & $27.4^{\mathrm{a}}$ & 2.0 & $27.4^{\mathrm{a}}$ & 1.7 & $45.0^{\mathrm{a}}$ & 8.7 & $29.0^{\mathrm{a}}$ & 4.4 & $28.4^{\mathrm{a}}$ & 1.9 \\
\hline Lactose, \% & $4.85^{\mathrm{a}}$ & 0.80 & $5.50^{\mathrm{a}}$ & 0.27 & $6.00^{\mathrm{a}}$ & 00.9 & $5.07^{a}$ & 0.81 & $5.60^{\mathrm{a}}$ & 0.24 & $5.99^{a}$ & 0.20 \\
\hline
\end{tabular}

Means with different letters were significantly different $\mathrm{a}, \mathrm{b}(\mathrm{P}<0.05)$. 
The general composition of colostrum and milk of sows receiving polyol supplement and sows on control feeding is presented in Table 3. The values are averages of 13 samples taken at each sampling. The colostrum samples were taken 12-16 hours after farrowing. The composition changed very soon post partum. The variation among samples of colostrum was quite wide: 15.7$22.5 \%$ for total solids, $0.56-0.92 \%$ for ash, $2.9-9.1 \%$ for fat, $4.9-12.3 \%$ for protein and 3.6-6.9 for lactose. The colostrum of sows given polyol supplementation tended to be richer in all constituents except fat in comparison with sows on the control ration.

The protein content fell rapidly after farrowing, 3-3.5 percentage points during the first week of lactation. During the same time the percentages of ash, fat and lactose rose. Polyol sows produced higher milk content of protein and lactose but lower fat content than the controls. However, the differences were not statistically significant owing to the wide variation among samples. The ash content at seven days post partum was lower in the polyol group $(\mathrm{P}<0.05)$. The lactose content was on average 0.1 percentage point higher sows in the polyol group than controls, possibly because of the polyols give in the diet.

The values found in the present study for sows colostrum and milk composition are in agreement with values given in the literature. The values for total solids and protein in colostrum are much lower than those reported by BRAUDE et al. (1947), Elliot et al. (1971) and FAнмy (1974) but this is mainly due to the different sampling time post partum. In the present study the samples were taken $12-16$ hours post partum whereas values given in literature are usually for samples taken during farrowing. The values of samples at 7 or 21 days post partum agree closely with those reported by Rook and WITTER (1968), Elsley (1971), Mahan et al. (1971), O'Grady et al (1973) and Chen et al. 1978).

The composition of minerals in the colostrum and milk of sows is shown in Table 4. The values are averages of 13 samples taken at each sampling. The phosphorus content was lower in colostrum than in milk, and the calcium in colostrum was only half of the content in milk. The calcium content in

Table 4. Mineral composition of colostrum and milk of sows.

\begin{tabular}{|c|c|c|c|c|c|c|c|c|c|c|c|c|}
\hline \multirow{3}{*}{$\begin{array}{l}\text { Time after } \\
\text { farrowing }\end{array}$} & \multicolumn{6}{|c|}{ Control diet } & \multicolumn{6}{|c|}{ Polyol diet } \\
\hline & \multicolumn{2}{|c|}{$12 \mathrm{~h}$} & \multicolumn{2}{|c|}{$7 \mathrm{~d}$} & \multicolumn{2}{|c|}{$21 \mathrm{~d}$} & \multicolumn{2}{|c|}{$12 \mathrm{~h}$} & \multicolumn{2}{|c|}{7} & \multicolumn{2}{|c|}{$21 \mathrm{~d}$} \\
\hline & $\overline{\mathbf{x}}$ & s.d. & $\bar{x}$ & s.d. & $\bar{x}$ & s.d. & $\overline{\mathbf{x}}$ & s.d. & $\overline{\mathbf{x}}$ & s.d. & $\overline{\mathbf{x}}$ & s.d. \\
\hline $\mathbf{n}$ & \multicolumn{2}{|c|}{13} & \multicolumn{2}{|c|}{13} & \multicolumn{2}{|c|}{13} & \multicolumn{2}{|c|}{13} & \multicolumn{2}{|c|}{13} & \multicolumn{2}{|c|}{13} \\
\hline Phosphorus, g/kg & $1.10^{\mathrm{a}}$ & 0.14 & $1.26^{\mathrm{a}}$ & 0.05 & $1.28^{\mathrm{a}}$ & 0.06 & $1.11^{\mathrm{a}}$ & 0.12 & $1.22^{\mathrm{a}}$ & 0.08 & $1.25^{\mathrm{a}}$ & 0.08 \\
\hline Calcium, g/kg & $0.70^{\mathrm{a}}$ & 0.08 & $1.53 \mathrm{a}$ & 0.28 & $1.62^{\mathrm{a}}$ & 0.14 & $0.80^{\mathrm{a}}$ & 0.18 & $1.62^{\mathrm{a}}$ & 0.23 & $1.57^{\mathrm{a}}$ & 0.13 \\
\hline Magnesium, mg/kg & $72.5^{a}$ & 12.2 & $75.1^{\mathrm{a}}$ & 7.1 & $80.0^{\mathrm{a}}$ & 7.3 & $71.7^{\mathrm{a}}$ & 8.2 & $71.7^{\mathrm{a}}$ & 7.8 & $74.4^{\mathrm{b}}$ & 5.1 \\
\hline Potassium, g/ka & $1.32^{\mathrm{a}}$ & 0.21 & $0.99 \mathrm{a}$ & 0.09 & $0.82^{\mathrm{a}}$ & 0.08 & $1.26^{\mathrm{a}}$ & 0.21 & $0.93^{\mathrm{a}}$ & 0.07 & $0.81^{\mathrm{a}}$ & 0.07 \\
\hline
\end{tabular}

Means with different letters were significantly different. (a, b $\mathrm{P}<0.05$ ). 
Table 5. Amino acid composition of colostrum and milk of sows at different sampling times.

\begin{tabular}{|c|c|c|c|c|c|c|c|c|c|c|c|c|}
\hline \multirow{3}{*}{$\begin{array}{l}\text { Amino acid } \\
\mathrm{g} / 100 \mathrm{~g} \text { protein }\end{array}$} & \multicolumn{6}{|c|}{ Control diet } & \multicolumn{6}{|c|}{ Polyol diet } \\
\hline & \multicolumn{2}{|c|}{$12 \mathrm{~h}$} & \multicolumn{2}{|c|}{$7 \mathrm{~d}$} & \multicolumn{2}{|c|}{$21 \mathrm{~d}$} & \multicolumn{2}{|c|}{$12 \mathrm{~h}$} & \multicolumn{2}{|c|}{$7 \mathrm{~d}$} & \multicolumn{2}{|c|}{$21 \mathrm{~d}$} \\
\hline & $\overline{\mathbf{x}}$ & s.d & $\overline{\mathbf{x}}$ & s.d. & $\overline{\mathbf{x}}$ & s.d & $\bar{x}$ & s.d. & $\overline{\mathbf{x}}$ & s.d. & $\bar{x}$ & s.d. \\
\hline $\mathbf{n}$ & \multicolumn{2}{|c|}{5} & \multicolumn{2}{|c|}{5} & \multicolumn{2}{|c|}{5} & \multicolumn{2}{|c|}{5} & \multicolumn{2}{|c|}{5} & \multicolumn{2}{|c|}{5} \\
\hline Alanine............. & 3.7 & 1.0 & 3.7 & 0.3 & 3.7 & 0.1 & 4.4 & 0.7 & 4.3 & 1.9 & 3.7 & 0.2 \\
\hline Arginine ............. & 3.8 & 1.0 & 4.3 & 0.5 & 4.4 & 0.2 & 3.9 & 1.6 & 4.9 & 1.8 & 4.4 & 0.2 \\
\hline Aspartic acid ...... & 6.5 & 1.4 & 7.2 & 0.5 & 7.3 & 0.2 & 7.6 & 0.7 & 8.0 & 2.9 & 6.5 & 1.5 \\
\hline Cystine ............... & 1.1 & 0.3 & 1.1 & 0.3 & 1.0 & 0.2 & 1.6 & 0.7 & 1.4 & 0.4 & 0.9 & 0.1 \\
\hline Glutamic acid ..... & 16.1 & 2.4 & 21.0 & 2.0 & 21.2 & 0.5 & 16.1 & 4.2 & 18.9 & 1.9 & 20.8 & 0.9 \\
\hline Glycine ............... & 2.8 & 0.7 & 3.1 & 0.3 & 3.2 & 0.1 & 3.3 & 0.5 & 3.5 & 1.4 & 3.2 & 1.2 \\
\hline Histidine ............. & 2.5 & 0.8 & 2.3 & 0.7 & 2.4 & 0.4 & 2.7 & 0.7 & 2.7 & 1.3 & 2.4 & 0.2 \\
\hline Isoleucine......... & 2.1 & 0.3 & 3.3 & 0.2 & 3.3 & 0.2 & 2.5 & 0.5 & 3.1 & 0.3 & 3.2 & 0.3 \\
\hline Leucine .............. & 8.3 & 2.0 & 8.7 & 0.7 & 8.9 & 0.6 & 9.4 & 0.7 & 9.8 & 3.8 & 8.6 & 0.3 \\
\hline Lysine .................. & 11.0 & 3.6 & 10.3 & 1.5 & 10.2 & 1.4 & 12.8 & 2.6 & 13.1 & 6.1 & 10.7 & 0.9 \\
\hline Methionine ......... & 1.0 & 0.2 & 1.3 & 0.1 & 1.3 & 0.1 & 1.1 & 0.1 & 1.3 & 0.4 & 1.2 & 0.1 \\
\hline Phenylalanine ....... & 3.9 & 0.9 & 4.1 & 0.3 & 4.1 & 0.1 & 4.6 & 0.5 & 4.6 & 1.8 & 4.1 & 0.2 \\
\hline Proline ............... & 9.2 & 1.6 & 11.6 & 1.0 & 11.7 & 0.5 & 9.8 & 0.5 & 12.1 & 3.9 & 11.2 & 0.5 \\
\hline Serine ................ & 51 & 1.4 & 5.1 & 0.4 & 5.1 & 0.1 & 6.1 & 1.4 & 6.1 & 3.0 & 5.1 & 0.2 \\
\hline Threonine ........... & 4.4 & 1.2 & 4.1 & 0.3 & 4.1 & 0.1 & 5.1 & 0.9 & 4.9 & 2.3 & 4.1 & 0.2 \\
\hline Tyrosine ............. & 2.4 & 0.4 & 3.6 & 0.8 & 3.3 & 0.3 & 2.7 & 0.8 & 3.1 & 0.2 & 3.2 & 0.3 \\
\hline Valine $. . . \ldots \ldots \ldots \ldots . . . .$. & 4.8 & 1.3 & 4.8 & 0.4 & 4.9 & 0.2 & 5.6 & 0.7 & 5.6 & 2.4 & 4.7 & 0.2 \\
\hline
\end{tabular}

colostrum of the polyol group was $0.10 \mathrm{~g} / \mathrm{kg}$ lower compared with the control. The value of calcium in milk was $1.5-1.6 \mathrm{~g} / \mathrm{kg}$, which was low compared with the values given by Elliot et al. (1971), FAHмy (1972) and Chen et al. (1978). The values of phosphorus were comparable with those reported in the literature. Magnesium content was the same in colostrum and milk, but at 21-days post partum was significantly lower $(\mathrm{P}<0.05)$ in the polyol than the control group. The magnesium values were a little below the values given by Elliot et al. (1971), FAHMy (1972) and ChEN et al. (1978). The potassium content in colostrum was $1.26-1.32 \mathrm{~g} / \mathrm{kg}$ and it decreased as the lactation progressed. Magnesium and potassium contents were lower at every sampling time in sows on the diet supplemented with polyol mixture.

The amino acid composition of colostrum and milk from sows is shown in Table 5. Values are reported as grams per 100 grams of milk protein and are averages of the five samples taken at each sampling time. The amounts of all amino acids of colostrum were greater in the polyol group than in the control group. A similar result was found for milk at seven days postpartum, except for the values of glutamic acid and tyrosine which were higher in the control group. At seven days postpartum the total amount of amino acids in colostrum was $12.2 \%$ and in milk $7.6 \%$ greater in the polyol group than the control group. At 21 days postpartum the values in milk were $1.9 \%$ smaller for the polyol group. The protein content of milk in the polyol group was $0.53,0.17$ and 0.17 percentage points higher than in the control group at the 
different sampling times: $12 \mathrm{~h}, 7 \mathrm{~d}$ and $21 \mathrm{~d}$ postpartum, respectively. The values obtained in this study correspond quite closely with values reported in the literature (ELLIOT et al. 1971, ElsLey 1971).

Acknowledgements. This study was made possible by the support of the Farmos Group, Agricultural Division and Finnish Sugar Co. The authors wish to express thanks to Miss HannaLeena Wejberg for technical assistance, Lea Huida, M. Sc., Agricultural Research Centre, Department of Animal Husbandry for amino acid determination and Anna Norrman, M.Sc. Finnish Sugar Centre for sugar alcohol analyses.

\section{REFERENCES}

Braude, R., Coates, M. E., Henry, K. M. ,Kon, S. K., Rowland, S. J., Thomson, S. Y. \& WALKer, D. M. 1947. A study of the composition of sow's milk. Brit. J. Nutr. 1:6477.

Chen, S. Y., D'Mello, J. P. F., Elsley, F. W. H. \& TaYlor, A. G. 1978. Effect of dietary lysine levels on performance nitrogen metabolism and plasma amino acid concentrations of lactating sows. Anim. Prod. 27: 331-344.

Elliot, R. F., Van der Noot, G. W., Gilbreath, R. L. \& Fisher, H. 1971. Effect of dietary protein level on composition changes in sow colostrum and milk. J. Anim. Sci. 32: $1128-1137$.

ElsLey, F. W. H. 1971. Nutrition and lactation in the sow. Lactation (Ed. I. R. Falconer), Butterworths, London. p. 393-411.

FАнму, M. H. 1972. Comparative study of colostrum and milk composition of seven breeds of swine. Can. J. Anim. Sci. 52: 621-627.

Korhonen, H., Rintamäki, O., Antila, M., Tuori, M. \& Poutiainen, E. 1977. A polyol mixture or molasses treated beet pulp in the silage based diet of dairy cows. II. The effect on the lactoperoxidase and thiocyanate content of milk and udder health. J. Scient. Agric. Soc. Finl. 49: 330-345.

Mahan, D. C., Becker, D. E., Harmon, B. G. \& Jensen, A. H. 1971. Effect of protein levels and Opaque-2 corn on sow milk composition. J. Anim. Sci. 32: 482-486.

Mäkinen, K. K., HämäLärnen, M., Tuori, M. \& Poutiainen, E. 1979 a. The effect of the consumption of a polyol mixture on the metabolism of serum, milk, whole saliva and lacrimal fluid in the cow. Internat. J. Vit. Nutr. Res. (In press).

- , Näsı, M. \& Alaviuhkola, T. 1979 b. Composition of sow milk during polyol feeding. Internat. J. Vit. Nutr. Res. (In press).

O'Grady, J. F., Elsleyy, F. W. H., MacPherson, R. M. \& McDonald, I. 1973. The response of lactating sows and their litters to different dietary energy allowances. I Milk yield and composition, reproductive performance of sows and growth rate of litters. Anim. Prod. 17: $65-74$.

Palohermo, L. 1969. Weender Analyse. Handb. Tierernăhrung I: 164-171. Hamburg.

Poutiainen, E., Tuori, M., Sirviö, I. 1976. The fermentation of polyalcohols by rumen microbes in vitro. Proc. Nutr. Soc. 35: $140 \mathrm{~A}$.

ReIter, B. 1978. Review of the progress of Dairy Science: antimicrobial systems in milk. J. Dairy Res. 45: $131-147$.

Rook, J. A. F. \& Witter, R. C. 1968. Diet and milk secretion in the sow. Proc. Nurt. Soc. 27: $71-76$.

Scheının, A. \& Mäkinen, K. K. 1975. Turku sugar studies I-XXI. Acta Odont. Scand. 33, suppl. 70 .

Steel, R. G. \& Torrie, J. H. 1960. Principles and procedures of statistics. 481 p. New York.

TAUssky, H. H. \& SHORR, E. 1953. A microcalorimetric method for the determination of inorganic phosphorus. J. Biol. Chem. 202: 675-685. 
Touster, O. 1974. The metabolism of polyols. Sugars in nutrition (Ed. H. L. Sipple and K. W. McNutt). London. p. 229-239.

Tuori, M. \& Poutiarnen, E. 1977. A polyol mixture or molasses treated beet pulp in the silage based diet of dairy cows. I. The effect on the feed utilization, milk yield and blood values. J. Scient. Agric. Soc. Finl. 49: 315-329.

Ms received October 26, 1979.

\section{SELOSTUS}

\section{Polyoliseos emakoiden ja porsaiden rehussa}

\section{MatTI NÄSI}

Helsingin yliopisto, kotieläintieteen laitos, 00710 Helsinki 71

Trmo AlaviuhKola

Sikatalouskoeasema, 05840 Hyvinkää 4

Tutkimuksessa selvitettiin polyolinlisäyksen (sokerialkoholiseos) vaikutusta porsaiden kasvuun, rehunkulutukseen ja ripulin esiintymiseen sekä emakonmaidon koostumukseen. Koe käsitti 26 pahnuetta ja oli faktoriaalinen $2 \times 2$, jossa emakot saivat $180 \mathrm{~g}$ polyoliliuosta tai $100 \mathrm{~g}$ ohraa normaalin rehuannoksen lisäksi ja porsaat porsasrehua, joka sisälsi joko $5 \%$ polyoliliuosta tai $2.5 \%$ glukoosi-fruktoosiseosta.

Vertailuryhmässä oli 10.3 ja polyoliryhmässä 9.2. porsasta/pahnue. Polyolilisäyksellä emakkoseoksessa ei ollut vaikutusta porsaiden kasvuun. Polyolia porsasrehussa saaneet ryhmät kasvoivat $10.1 \%$ paremmin kuin vertailuryhmät. Ero ei ollut merkitsevä kun porsaiden lukumäärä pahnuetta kohti otetaan huomioon. Ripulitapauksia oli polyolia saaneilla pahnueilla hieman enemmän.

Emakoista otettiin maitonäytteitä 12 tuntia sekä 7 ja 21 päivää porsimisesta. Maitonäytteistä määritettiin kuiva-aine, tuhka, rasva, valkuainen, laktoosi, kivennäis- ja hivenaineet sekä aminohapot. 